\title{
Removal of Hexavalent Chromium from Aqueous Solution by the Pod of Acacia gerrardii
}

\author{
Mohammed A. Abdulaziz ${ }^{*}$, Abdulrahman A. Bakri ${ }^{1}$, Saleh A. Al-Zahrani ${ }^{1}$, Majed S. Al-Zahrani ${ }^{1}$, \\ Abdulrahman N. Al-Lehebi ${ }^{1}$, Fadil M. Banjar ${ }^{1}$, Mohand I. Nabag ${ }^{2}$ \\ ${ }^{1}$ Umm Al-Qura University, Department of Environmental Health, Faculty of Public Health and Health Informatics, \\ Makkah, Saudi Arabia \\ ${ }^{2}$ Umm Al-Qura University, Department of Epidemiology, Faculty of Public Health and Health Informatics, Makkah, \\ Saudi Arabia \\ "Corresponding author: e-mail: dr.mohammed012@yahoo.com
}

\begin{abstract}
This study aims at investigating the potential of Acacia gerrardii pod for the removal of $\mathrm{Cr}(\mathrm{VI})$ in batch system. Effect of solution $\mathrm{pH}$, biosorbent dosage, initial concentration of $\mathrm{Cr}(\mathrm{VI})$, contact time on the removal process was examined. Complete removal of hexavalent chromium was achieved at $\mathrm{pH}$ values 1.0 and 2.0 whereas maximum removal of total chromium was obtained at $\mathrm{pH}$ of 3.0. The study showed that the biosorption and bioreduction mechanisms were involved in the removal process. The time required for complete removal of $\mathrm{Cr}(\mathrm{VI})$ using the pod of Acacia gerrardii was shortened with an increase in biomaterial dosage and decrease in $\mathrm{Cr}(\mathrm{VI})$ concentration. Kinetic data was well described using Park kinetic model. Freundlich isotherm model adequately fitted the equilibrium data indication multilayer adsorption of total chromium on the surface of biomaterial. The pod of Acacia gerrardii could be used efficiently for the removal of hexavalent chromium from aqueous solutions.
\end{abstract}

Keywords: Biosorption, chromium, Acacia gerrardii, isotherm models, Park kinetic models.

\section{INTRODUCTION}

Chromium is widely used in many industrial applications such as electroplating, leather tanning, wood preservation, chromate production, petroleum refining, and oxidants in University laboratories ${ }^{1}$. Chromium is presents in environment in two stable forms, hexavalent chromium $(\mathrm{Cr}(\mathrm{VI}))$ and trivalent chromium (Cr(III)). Compared to $\mathrm{Cr}(\mathrm{III})$, hexavalent chromium has higher mobility, bioavailability and toxicity ${ }^{2}$.

If inadequately treated, chromium-bearing effluents can result in serious environmental health hazard. Toxic effects of chromium include dermatitis, bronchitis, liver dysfunction, renal impairment and cancer ${ }^{3}$.

Several organizations and governmental bodies have set regulations and standard to restrict the discharge of toxic chromium to the environment. Though the removal of hexavalent chromium from industrial effluents to be within the regulatory limit is obligatory ${ }^{4}$.

Many traditional technologies including chemical precipitation are used to sequester hexavalent chromium from industrial wastewaters ${ }^{5}$. Chemical precipitation of hexavalent chromium involves the chemical reduction of $\mathrm{Cr}(\mathrm{VI})$ to $\mathrm{Cr}(\mathrm{III})$ at lower $\mathrm{pH}$ condition followed by precipitation of $\mathrm{Cr}(\mathrm{III})$ as $\mathrm{Cr}(\mathrm{OH})_{3}$ at higher $\mathrm{pH}$ values ${ }^{6}$. The chemicals involved in reduction and precipitation process are hazardous and expensive ${ }^{7}$. Furthermore, the toxic sludge generated from this method needs extensive treatment before disposal ${ }^{8}$.

The adsorption of heavy metals from wastewaters is obtained using activated carbon and polymer resin, which are expensive 9 . Recently, several researchers have reported the ability of biomaterials to adsorb and reduce $\mathrm{Cr}(\mathrm{VI})$ to less toxic $\mathrm{Cr}(\mathrm{III})$.

The term "biosorption" was applied to the process by which the contaminants are removed by inactive biomass ${ }^{10}$. This technology utilizes the naturally available, low cost and eco-friendly biomaterial for decontamination of industrial wastewaters ${ }^{11}$.

Various biomaterials have been tested for the removal of hexavalent chromium such as Sargassum cymosum ${ }^{12}$, Oak peel ${ }^{13}$, Prunus serotina bark ${ }^{14}$, husk of Lathyrus sativus $^{15}$, banana skin $^{16}$, Ficus carica ${ }^{17}$, wood apple shell ${ }^{18}$; dried pineapple leaves ${ }^{19}$, Ecklonia $^{20}$.

The removal mechanism of hexavalent chromium from aqueous medium was considered by several studies as a simple anionic adsorption on the surface of protonated biomass whereas several researchers argued the contribution of reduction to the removal process under acidic conditions.

The pods of Acacia spp were reported to contain tannins ${ }^{21}$ which exhibited specific affinity to bind metal ions $^{22}$. The pod of Acacia gerrardii is naturally available and being produced in plant nursery as a waste materials. In the present study, an attempt has been made to examine the potential of Acacia gerrardii pods for the removal of $\mathrm{Cr}(\mathrm{VI})$ from contaminated water. The study describes the adsorption and reduction mechanisms involved in the removal process.

\section{EXPERIMENTAL}

\section{Preparation of biomaterial}

The pod of Acacia gerrardii was collected from Al-Baha Emirate in Saudi Arabia. The pod was washed by water to remove any debris that might be attached to its surface. The pod then was air dried, grounded by mixer, sieved using 120 mesh and stored in glass bottle.

\section{Preparation of $\mathrm{Cr}(\mathrm{VI})$ solutions}

The stock solution of $\mathrm{Cr}(\mathrm{VI})$ of $500 \mathrm{mg} / \mathrm{L}$ was prepared by dissolving analytical grade potassium dichromate in distilled water. Working solutions were prepared by adequate dilution of stock solution with distilled water. 


\section{Experiments for $\mathrm{Cr}(\mathrm{VI})$ removal}

Batch experiments were carried out in $100 \mathrm{ml}$ conical flasks containing mixtures of $\mathrm{Cr}(\mathrm{VI})$ solution and pods of Acacia gerrardii. The mixture was shaken in shaking incubator till the equilibrium was reached except in the case of kinetic studies where the samples from the $\mathrm{Cr}(\mathrm{VI})$ solution were collected at different time intervals. At the end of each experiment, the mixture of biomaterial and $\mathrm{Cr}(\mathrm{VI})$ solution was filtered and the filtrates was analyzed for $\mathrm{Cr}(\mathrm{VI})$, total $\mathrm{Cr}$ and $\mathrm{Cr}$ (III) concentrations following standard method ${ }^{23}$. Effect of $\mathrm{pH}$ on the removal process was evaluated by varying the $\mathrm{pH}$ of $\mathrm{Cr}(\mathrm{VI})$ solution in the range of 1.0-7.0. This variation was gained by proper addition of $\mathrm{HCl}(0.1 \mathrm{M})$ and 0.1 $\mathrm{M} \mathrm{NaOH}(0.1 \mathrm{M})$. Hexavalent chromium solution of 20 $\mathrm{mg} / \mathrm{L}$ was added to $0.1 \mathrm{~g}$ of Acacia gerrardii pod and mixed in shaking incubator for the period of 18 hours to ensure equilibrium.

In kinetic experiments, various concentration Acacia gerrardii pod (1.0-3.0 g/L) was added to $\mathrm{Cr}(\mathrm{VI})$ solutions with concentration of $40 \mathrm{mg} / \mathrm{L}$. The samples from the $\mathrm{Cr}(\mathrm{VI})$ solution were collected at different time intervals.

To study the adsorption isotherm, different concentrations of $\mathrm{Cr}(\mathrm{VI})$ solutions were prepared $(20 \mathrm{mg} / \mathrm{L}, 40$ $\mathrm{mg} / \mathrm{L}, 60 \mathrm{mg} / \mathrm{L}, 80 \mathrm{mg} / \mathrm{L}, 100 \mathrm{mg} / \mathrm{L}$ and $120 \mathrm{mg} / \mathrm{L}$ ) and mixed with $0.4 \mathrm{~g}$ of the pods of Acacia gerrardii for the period of 24 hours. All experiments were conducted at temperature of $30^{\circ} \mathrm{C}$.

The solution $\mathrm{pH}$ was adjusted to the value of 2.0 in both kinetic and adsorption isotherm experiments. The uptake of metals by Acacia gerrardii pod calculated using the following equation;

$q_{e}=\frac{\left(C_{i}-C_{e}\right) \times V}{m}$

where $q_{e}$ is the total chromium ion adsorbed (mg metal ion/ $\mathrm{g}$ biosorbent) at equilibrium, $V$ is the volume of the solution ( $\mathrm{L}), \mathrm{C}_{\mathrm{i}}$ and $\mathrm{C}_{\mathrm{e}}$ are the initial and equilibrium concentration of $\mathrm{Cr}(\mathrm{VI})$ ion $(\mathrm{mg} / \mathrm{L})$ and $m$ is the dry weight of the Acacia gerrardii (g).

\section{Chromium analysis}

Hexavalent chromium was analyzed using diphenylcarbazide method in acidic medium. A measured volume of the supernatants were mixed with $3 \mathrm{~mL} 6 \mathrm{~N} \mathrm{H}_{2} \mathrm{SO}_{4}$ followed by $2 \mathrm{~mL}$ of diphenylcarbazide. The total volume was made up to $50 \mathrm{ml}$ using double distilled water. The resulted red-violet complex was measured at $540 \mathrm{~nm}$ using spectrophotometer (Spectro 20d Plus Spectrophotometer, Labomed, Inc).

Total chromium concentration was analyzed using flame atomic absorption spectrometer following the instrument operational manual (Agilent 55 AA Atomic Absorption Spectrometer). Trivalent chromium was calculated as the difference between total chromium and hexavalent chromium.

\section{RESULTS AND DISCUSSION}

\section{Effect of $\mathbf{p H}$}

Solution $\mathrm{pH}$ is the most important determinant factor for the removal of heavy metals from aqueous solution. The effect of $\mathrm{pH}$ on the removal of $\mathrm{Cr}(\mathrm{VI})$ by the pod of Acacia gerrardii was presented in Fig.1. The figure demonstrates the complete removal of $\mathrm{Cr}(\mathrm{VI})$ from the solution at $\mathrm{pH}$ values of 1.0 and 2.0 whereas $90.2 \%$ removal was achieved at $\mathrm{pH}$ 3.0. The removal efficiency was decreased significantly with increasing the $\mathrm{pH}$ from 4.0 to 7.0. This indicates the favorable removal of $\mathrm{Cr}(\mathrm{VI})$ using the pod of Acacia gerrardii at acidic conditions. Similar trends were reported for the biosorption of $\mathrm{Cr}(\mathrm{VI})$ by other biomaterials ${ }^{24}$.

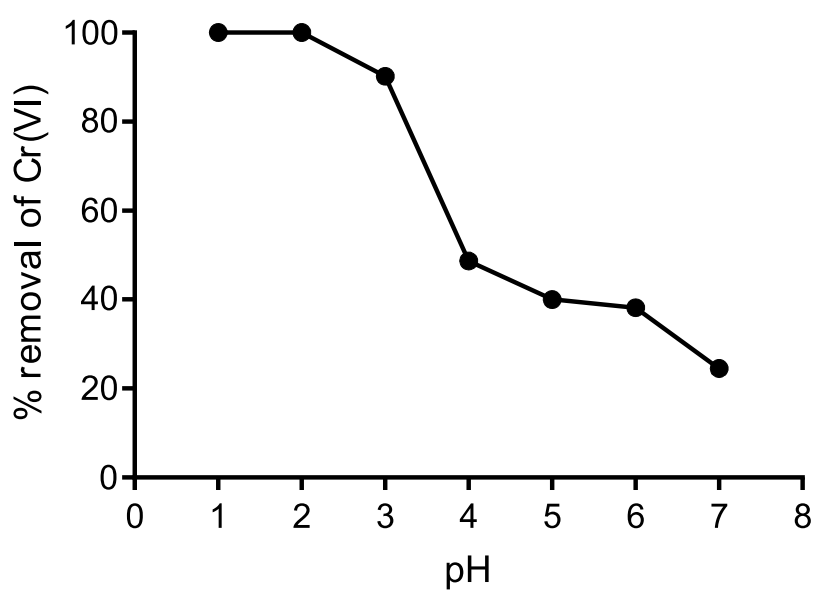

Figure 1. Effect of Solution $\mathrm{pH}$ on the removal efficiency of $\mathrm{Cr}(\mathrm{VI})$ using the pod of Acacia gerrardii (Initial $\mathrm{Cr}(\mathrm{VI})$ concentration $=20 \mathrm{mg} / \mathrm{L}$, biomaterial dosage $=1.0 \mathrm{~g} / \mathrm{L}$, Temperature $=30^{\circ} \mathrm{C}$ and rotation speed $=200 \mathrm{rpm}$.)

It is known that the $\mathrm{pH}$ affects the speciation of metal ions in the aqueous solutions as well as the surface chemistry of biomaterials. The expected forms of $\mathrm{Cr}(\mathrm{VI})$ in natural water are $\mathrm{HCrO}_{4}^{-}, \mathrm{CrO}_{4}^{-2}$ and $\mathrm{Cr}_{2} \mathrm{O}_{7}^{-2}$ ions with $\mathrm{HCrO}_{4}^{-}$is predominant in lower $\mathrm{pH}$ values ${ }^{25}$. At strong acidic condition, biomaterials are subjected to the protonation process in which the protons coordinate with functional groups on the surface of biomaterials ${ }^{\mathbf{2 0}}$. Thus, this protonation enhanced the electrostatic attraction of positively charged Acacia gerrardii pod and anionic forms of $\mathrm{Cr}(\mathrm{VI})$. In contrary, the repulsive force between the anionic form of $\mathrm{Cr}(\mathrm{VI})$ and deprotonated pod of Acacia gerrardii resulted in low removal efficiency at higher $\mathrm{pH}$ values.

For further understanding the removal mechanism of $\mathrm{Cr}(\mathrm{VI})$ by the pod of Acacia gerrardii, the equilibrium concentrations of $\mathrm{Cr}(\mathrm{VI})$, total $\mathrm{Cr}$ and $\mathrm{Cr}(\mathrm{III})$ are plotted against the studied range of $\mathrm{pH}$ values (Fig. 2). The figure shows the appearance of $\mathrm{Cr}$ (III) which was not present in the solutions before running the experiments. The concentration of $\mathrm{Cr}$ (III) was decreased as the $\mathrm{pH}$ of the solutions increased from 1.0 to 7.0 indicating the reduction of $\mathrm{Cr}(\mathrm{VI})$ to $\mathrm{Cr}(\mathrm{III})$ at lower $\mathrm{pH}$ values by the electronic donor groups exists on the surface of Acacia gerrardii pod. These results lead to the assumption that both biosorption and bioreduction mechanisms were involved in the removal process of $\mathrm{Cr}(\mathrm{VI})$ by the pod of Acacia gerrardii pod.

Park proposed two reduction mechanisms (direct and indirect) for $\mathrm{Cr}(\mathrm{VI})$ by biomaterials in his subsequent literatures ${ }^{\mathbf{2 6 - 2 8}}$. In the direct mechanism, the $\mathrm{Cr}(\mathrm{VI})$ is reduced by the biomaterial to $\mathrm{Cr}$ (III), which in turn remains in the solution or forms complex with functional group of the biosorbent. Direct reduction mechanism is based on 
the assumption that the anionic forms of $\mathrm{Cr}(\mathrm{VI})$ binds to the protonated functional groups of biomaterials before its reduction to $\mathrm{Cr}$ (III) by the adjacent electron-donor groups. The resulted $\mathrm{Cr}$ (III) are released to the solution due to repulsive force between protonated biomaterials and cationic $\mathrm{Cr}(\mathrm{III})$. The reduction reaction takes place according to the following equations;

$$
\begin{array}{lc}
\mathrm{Cr}_{2} \mathrm{O}_{7}^{2-}+14 \mathrm{H}^{+}+6 e^{-} \rightarrow 2 \mathrm{Cr}^{3+}+7 \mathrm{H}_{2} \mathrm{O} & E^{0}=+1.33 \mathrm{~V} \\
\mathrm{HCrO}_{4}^{-}+7 \mathrm{H}^{+}+3 e^{-} \rightarrow \mathrm{Cr}^{3+}+4 \mathrm{H}_{2} \mathrm{O} & E^{0}=+1.35 \mathrm{~V} \\
\mathrm{H}_{2} \mathrm{CrO}_{4}+6 \mathrm{H}^{+}+3 e^{-} \rightarrow \mathrm{Cr}^{3+}+4 \mathrm{H}_{2} \mathrm{O} & E^{0}=+1.33 \mathrm{~V}
\end{array}
$$

As depicted from Fig. 2, the minimum concentration of total chromium was obtained at $\mathrm{pH}$ 3.0, which indicates maximum removal of total chromium by the pod of Acacia gerrardii at this acidic condition. This can be explained by the fact that higher amount of $\mathrm{Cr}$ (III) was added to the solution at $\mathrm{pH}<3.0$ as a result of $\mathrm{Cr}(\mathrm{VI})$ reduction by the pod of Acacia gerrardii. On the other hand, the biosorption efficiency of anionic $\mathrm{Cr}(\mathrm{VI})$ on the pod of Acacia gerrardii was decreased with an increase of $\mathrm{pH}$ values to the above of 3.0.

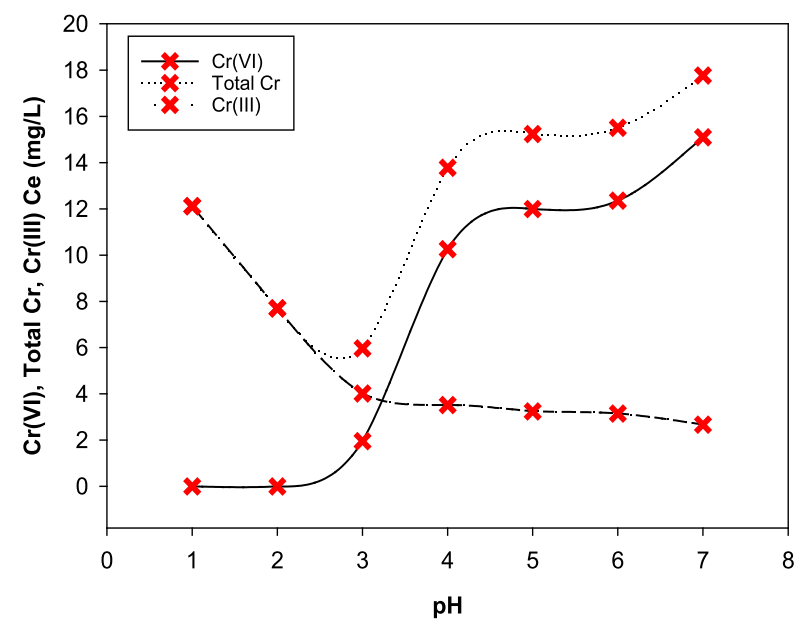

Figure 2. Chromium concentration profile during the removal of $\mathrm{Cr}(\mathrm{VI})$ using the pod of Acacia gerrardii at different acidic conditions (Initial $\mathrm{Cr}(\mathrm{VI})$ concentration = $20 \mathrm{mg} / \mathrm{L}$, biomaterial dosage $=1.0 \mathrm{~g} / \mathrm{L}$, Temperature $=30^{\circ} \mathrm{C}$ and rotation speed $=200 \mathrm{rpm}$.)

\section{Kinetic studies of $\mathrm{Cr}(\mathrm{VI})$ removal}

Effect of contact time and adsorbent dosage on the removal of $\mathrm{Cr}(\mathrm{VI})$ using the pod of Acacia gerrardii was presented in Fig. 3. It is indicated from the figure that higher concentration of Acacia gerrardii pod shortened the required time to reduce the concentration of $\mathrm{Cr}(\mathrm{VI})$ to the below of its detection limit. Fig. 3 shows the increase of $\mathrm{Cr}$ (III) concentration with time indicating the reduction of $\mathrm{Cr}(\mathrm{VI})$ to $\mathrm{Cr}(\mathrm{III})$. On the other hand, it has been observed that the amount of $\mathrm{Cr}(\mathrm{VI})$ removed from solution was higher than the amount of $\mathrm{Cr}$ (III) at each point of time demonstrating the simultaneous adsorption and reduction of $\mathrm{Cr}(\mathrm{VI})$ using the pod of Acacia gerrardii. After disappearance of $\mathrm{Cr}(\mathrm{VI})$ in the solution, there was no significant removal of total chromium with time suggesting the low adsorption capacity of $\mathrm{Cr}$ (III) on the surface of biomaterial at acidic condition. This can be due to repulsive force between the cationic ions of $\mathrm{Cr}$ (III) and protonated biomaterial at lower $\mathrm{pH}$ values.
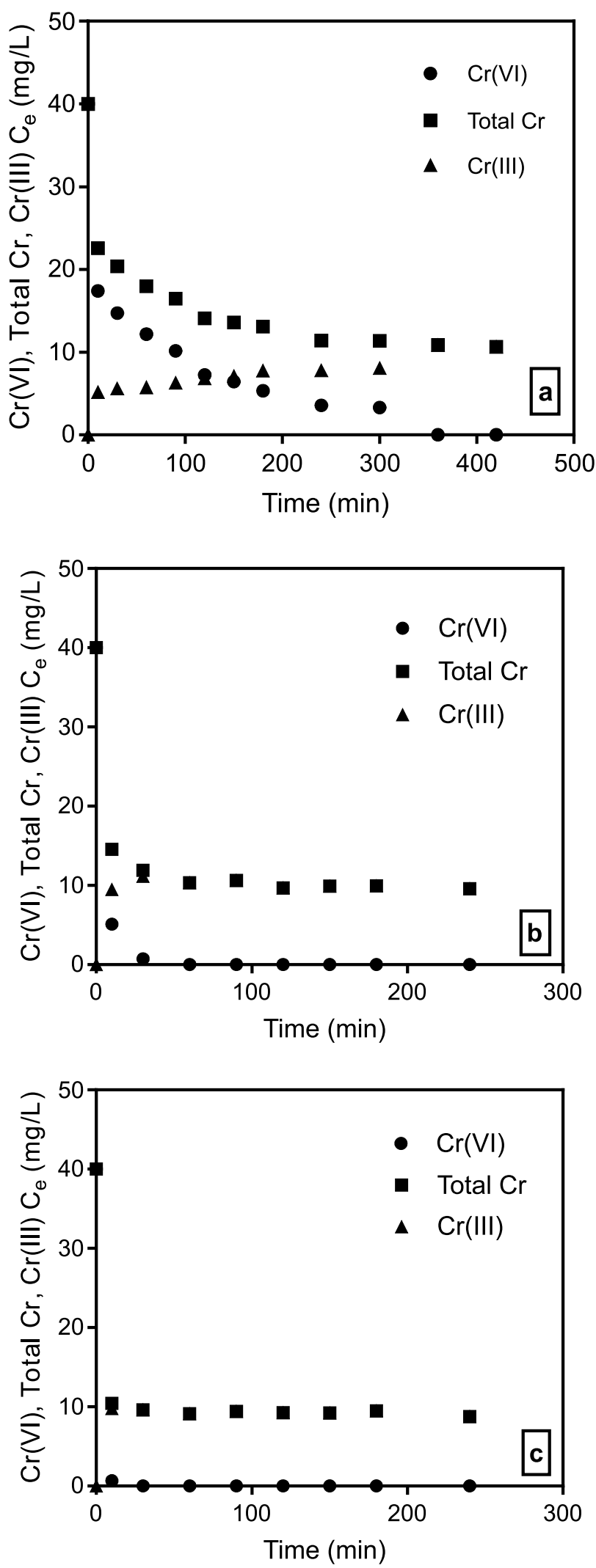

Figure 3. Chromium concentration during the removal of $\mathrm{Cr}(\mathrm{VI})$ using the pods of Acacia gerrardii. $\mathrm{pH}=2$, initial $\mathrm{Cr}$ (VI) concentration $=40 \mathrm{mg} / \mathrm{L}$, Temperature $=30^{\circ} \mathrm{C}$, rotation speed $=200 \mathrm{rpm}$ and biomaterial dosage was (a) $1.0 \mathrm{~g} / \mathrm{L}$ and (b) $2.0 \mathrm{~g} / \mathrm{L} \mathrm{(c)} 3 \mathrm{~g} / \mathrm{L}$

\section{Kinetic modeling}

Since the biosorption and bioreduction mechanisms were involved in the removal of $\mathrm{Cr}(\mathrm{VI})$ from aqueous solutions, Park kinetic model ${ }^{27}$ was used to describe the removal kinetic of $\mathrm{Cr}(\mathrm{VI})$ by the pod of Acacia gerrardii. This model is based on the following redox reaction 
between biosorbent and $\mathrm{Cr}(\mathrm{VI})$ during the biosorption process:

biomass $+\operatorname{Cr}(V I) \rightarrow$ biomass (oxidized $)+C r(I I I)$

The model considers the following assumption: (1) organic compounds on the surface of biomaterials are responsible for $\mathrm{Cr}(\mathrm{VI})$ reduction (2) one type of organic compounds has the ability to reduce $\mathrm{Cr}(\mathrm{VI})$ (3) the rate equation of $\mathrm{Cr}(\mathrm{VI})$ reduction is first order (Eq. 6)

$\frac{d[C r(V I)]}{d t}=-k[O C][C r(V I)]$

Where $\mathrm{OC}$ is the concentration of organic compounds at time $\mathrm{t}$ (minute) which is capable of reducing $\mathrm{Cr}(\mathrm{VI})$ in $(\mathrm{mmol} / \mathrm{L}), \mathrm{Cr}(\mathrm{VI})$ is the concentration of hexavalent chromium at time $\mathrm{t}(\mathrm{mmol} / \mathrm{L})$, is the rate constant ( $\mathrm{L} \mathrm{mmol}{ }^{-1} \mathrm{~m}^{-1}$ ).

The general form of Park model can be expressed as follows;

$[\operatorname{Cr}(V I)]=\frac{C_{O C}^{*}[B][C r(V I)]_{0}-[\operatorname{Cr}(V I)]_{0}^{2}}{C_{O C}^{*}[B] \exp \left(k\left(C_{O C}^{*}[B]-[\operatorname{Cr}(V I)]_{0}\right) t\right)-[\operatorname{Cr}(V I)]_{0}}$

Where $C_{O C}^{*}$ is the content of equivalent organic compound per unit gram of biomass $(\mathrm{mmol} / \mathrm{g})[\operatorname{Cr}(V I)]_{0}$ is the initial concentration of $\mathrm{Cr}(\mathrm{VI})(\mathrm{mmol} / \mathrm{L})$ and is the concentration of biomaterial $(\mathrm{g} / \mathrm{L})$.

Fig. 4 shows that the Park model could describe the $\mathrm{Cr}(\mathrm{VI})$ reduction kinetic at different dose of the pod of Acacia gerrardii. The constant values of $C_{O C}^{*}$ and are determined using the nonlinear equation regression with the help of GraphPad Prism 7.04. The parameters calculated values from the model are listed in Table 1. The removal rate constant increased with an increase in the biomaterial dosage from 1.0 to $3.0 \mathrm{~g} / \mathrm{L}$. This can be attributed to the higher availability of electrons required for reduction reaction with increasing the biomaterial concentration $^{29}$.

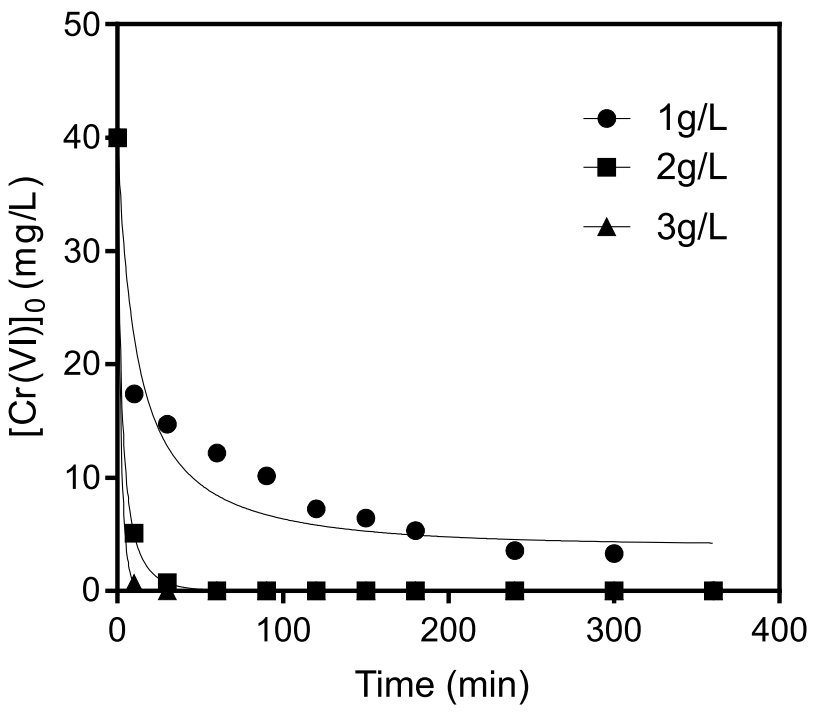

Figure 4. Chromium concentration during the removal of $\mathrm{Cr}$ (VI) using the various concentration of the pods of Acacia gerrardii. $\mathrm{pH}=2$, initial $\mathrm{Cr}$ (VI) concentration $=40 \mathrm{mg} / \mathrm{L}$, Temperature $=30^{\circ} \mathrm{C}$, rotation speed $=$ $200 \mathrm{rpm}$ and biomaterial dosage was (a) $1.0 \mathrm{~g} / \mathrm{L}$ and (b) $2.0 \mathrm{~g} / \mathrm{L}$ (c) $3 \mathrm{~g} / \mathrm{L}$. Symbols are the experimental data whereas lines are the predicted data from the model
Table 1. Estimated parameters of Park kinetic model for the removal of Cr (VI) using the pod of Acacia gerrardii. $\mathrm{pH}=2$, initial $\mathrm{Cr}(\mathrm{VI})$ concentration $=40 \mathrm{mg} / \mathrm{L}$, temperature $=300 \mathrm{C}$, rotation speed $=200 \mathrm{rpm}$ and biomaterial dosage was (a) $1.0 \mathrm{~g} / \mathrm{L}$ and (b) $2.0 \mathrm{~g} / \mathrm{L} \mathrm{(c)}$ $3 \mathrm{~g} / \mathrm{L}$

\begin{tabular}{|l|c|c|c|}
\hline \multirow{2}{*}{ Biosorbent dosage } & \multicolumn{3}{|c|}{ Park kinetic model parameters } \\
\cline { 2 - 4 } & $C_{O C}^{*}(\mathrm{mmol} / \mathrm{g})$ & $\mathrm{K}\left(\mathrm{L} \mathrm{mmol}^{-1} \mathrm{~m}^{-1}\right)$ & $\mathrm{R}^{2}$ \\
\hline $1 \mathrm{~g} / \mathrm{L}$ & 0.69 & 0.002 & 0.934 \\
\hline $2 \mathrm{~g} / \mathrm{L}$ & 0.09 & 0.009 & 1.00 \\
\hline $3 \mathrm{~g} / \mathrm{L}$ & 0.28 & 0.040 & 1.00 \\
\hline
\end{tabular}

\section{Adsorption isotherm modeling}

Since it is difficult to determine the form of chromium ions on the surface of biomaterial, adsorption isotherm models were used to describe the adsorption of total chromium on the surface of the pod of Acacia gerrardii. These models link the amount of metal ions adsorbed on unit mass of biosorbent at specific temperature. The models applied to obtained equilibrium data are namely; Langmuir adsorption isotherm model and Freundlich adsorption isotherm model.

The linear forms of Langmuir and Freundlich adsorption isotherm models are expressed in Eq. 8 and Eq. 9 respectively.

$\frac{C_{e}}{q_{e}}=\frac{1}{K_{L} \times q_{\max }}+\frac{C_{e}}{q_{\max }}$

Where $q_{\max }$ is the maximum biosorption capacity of adsorbent $(\mathrm{mg} / \mathrm{g})$ and $K_{L}$ is the Langmuir biosorption constant $(\mathrm{L} / \mathrm{mg})$. The values of $\mathrm{q}_{\max }$ and $\mathrm{K}_{\mathrm{L}}$ are calculated from the slope and intercept of the linear plot of $\mathrm{C}_{\mathrm{e}} / \mathrm{q}_{\mathrm{e}}$ versus $\mathrm{C}_{\mathrm{e}}$ (Fig. 5) respectively.

$\frac{C_{e}}{q_{e}}=\frac{1}{K_{L} \times q_{\max }}+\frac{C_{e}}{q_{\max }}$

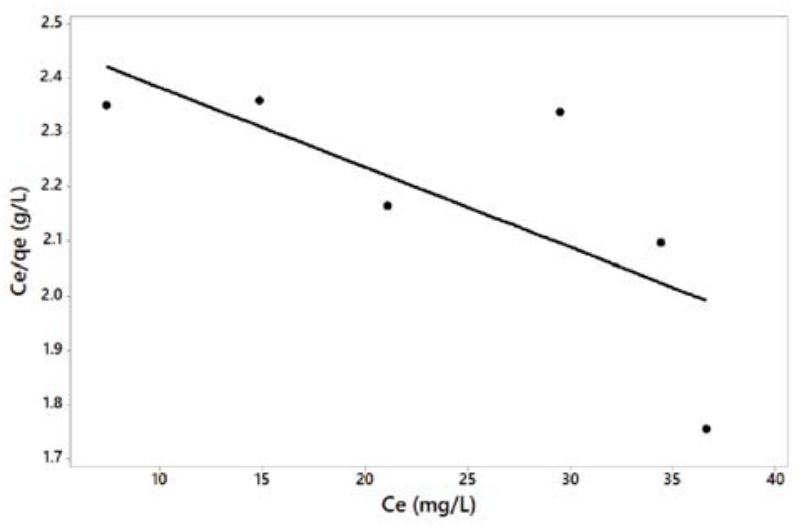

Figure 5. Langmuir adsorption isotherm for the sorption of total chromium by the pods of Acacia gerrardii

The Freundlich isotherm constants $1 / n$ and $K_{f}(\mathrm{~L} / \mathrm{g})$ are calculated from the slopes and intercepts of the linear plot of $\log \mathrm{q}_{\mathrm{e}}$ versus $\log \mathrm{C}_{\mathrm{e}}$ (Fig. 6).

The calculated values of the models constants are presented in Table 2 and the graphical presentations of . The Freundlich adsorption isotherm model showed better applicability $\left(\mathrm{R}^{2}=0.984\right)$ to equilibrium data indicating multilayer adsorption of chromium on heterogeneous surface. The higher value of $1 / \mathrm{n}(1 / n>1)$ indicates biosorption over the studied range of concentrations was not the favorable. 
Table 2. Adsorption isotherm models for the biosorption of total chromium by the pod of Acacia gerrardii. $\mathrm{pH}=2$, biomaterial dosage $=4 \mathrm{~g} / \mathrm{L}$, temperature $=30^{\circ} \mathrm{C}$ and rotation speed $=200 \mathrm{rpm}$

\begin{tabular}{|l|c|c|c|c|c|c|}
\hline Adsorption model & \multicolumn{3}{|c|}{ Langmuir isotherm model } & \multicolumn{3}{|c|}{ Freundlich isotherm model } \\
\hline Parameters & $q_{\max }(\mathrm{mg} / \mathrm{g})$ & $K_{L}(\mathrm{~L} / \mathrm{mg})$ & $R^{2}$ & $K_{f}(\mathrm{~L} / \mathrm{g})$ & $1 / n$ & $R^{2}$ \\
\hline & 68.21 & 0.005 & $\mathrm{~N}^{*} \mathrm{~F}^{*}$ & 3.09 & 1.11 & 0.984 \\
\hline
\end{tabular}

\section{* Not fitted}

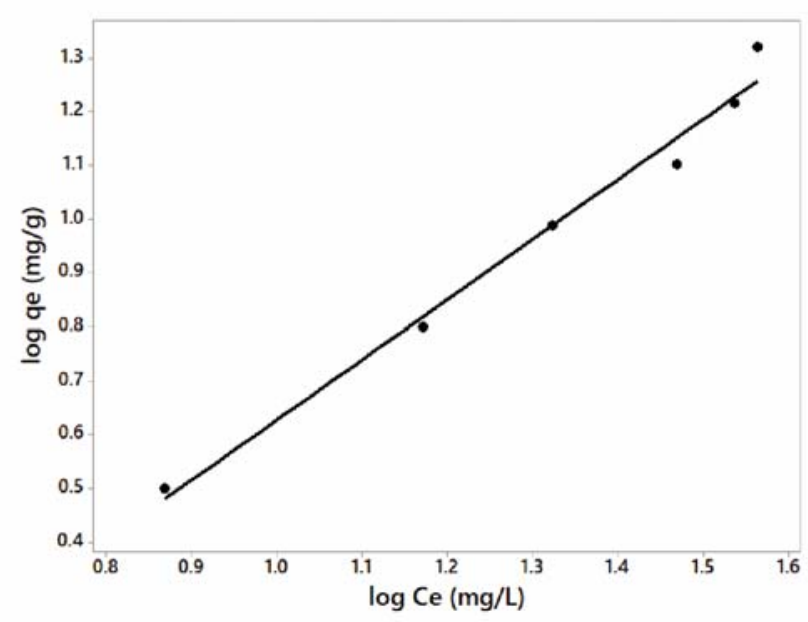

Figure 6. Freundlich adsorption isotherm for the sorption of total chromium by the pods of Acacia gerrardii

\section{CONCLUSIONS}

The pod of Acacia gerrardii has proved to be an efficient biomaterial for the removal of hexavalent chromium from aqueous solutions. The removal efficiency was dependent on the acidic conditions of the solutions. An increases in the $\mathrm{pH}$ of the solution resulted in the decrease of the removal of $\mathrm{Cr}(\mathrm{VI})$ by the used biomaterial. Complete removal of $\mathrm{Cr}(\mathrm{VI})$ was observed at the acidic conditions $(\mathrm{pH} \leq 2.0)$ whereas maximum removal of total chromium was observed at $\mathrm{pH}$ of 3.0. Trivalent chromium which was not available initially in the solutions appeared after biosorption process indicating the reduction of $\mathrm{Cr}(\mathrm{VI})$ to $\mathrm{Cr}$ (III) by the pod of Acacia gerrardii at strong acidic conditions. The Park model fitted well with the kinetic data at all ranges of the biosorbent dosages. An increase in the biosorbent dose resulted in increasing the removal rate of $\mathrm{Cr}(\mathrm{VI})$ by the pod of Acacia gerrardii. The uptake of $\mathrm{Cr}(\mathrm{VI})$ by the used biomaterial increased with increasing the dose of biosorbent and shortened the equilibrium time. The equilibrium data of total chromium removal was described well using the Freundlich adsorption model suggesting multilayer adsorption mechanisms.

\section{ACKNOWLEDGEMENTS}

The authors would like to thank the Institute of Scientifc Research and Revival of Islamic Heritage at Umm Al-Qura University (project No. 43509034) for fnancial support.

\section{LITERATURES CITED}

1. Murugavelh, S. \& Mohanty, K.K. (2012). Bioreduction of hexavalent chromium by free cells and cell free extracts of Halomonas sp. Chem. Eng. J. 203, 415-422. DOI: 10.1016/j. cej.2012.07.069.
2. Han, X., Wong, Y.S., Wong, M.H. \& Tam, N.F.Y. (2007). Biosorption and bioreduction of $\mathrm{Cr}(\mathrm{VI})$ by a microalgal isolate, Chlorella miniata. J. Hazard. Mater. 146 (1-2), 65-72. DOI: 10.1016/j.jhazmat.2006.11.053.

3. Saha, B. \& Orvig, C. (2010). Biosorbents for hexavalent chromium elimination from industrial and municipal effluents. Coord. Chem. Rev. 254 (23-24), 2959-2972. DOI: 10.1016/j. ccr.2010.06.005.

4. Ye, J., Yin, J., Mai, B., Peng, H., Qin, H., He, B. \& Zhang, N. (2010). Biosorption of chromium from aqueous solution and electroplating wastewater using mixture of Candida lipolytica and dewatered sewage sludge. Bioresour. Technol. 101 (11), 3893-3902. DOI: 10.1016/j.biortech.2010.01.014.

5. Kavita, B., Limbachia, J. \& Keharia, H. (2011). Hexavalent chromium sorption by biomass of chromium tolerant Pythium sp. J. Basic Microbiol. 51, 173-182. DOI: 10.1002/jobm.201000191.

6. Vieira, R.S., Meneghetti, E., Baroni, P., Guibal, E., Cruz, V.M.G., Caballero, A., Rodríguez-Castellón, E. \& Beppu, M.M. (2014). Chromium removal on chitosan-based sorbents - An EXAFS/XANES investigation of mechanism, Mater. Chem. Phys. 146, 412-417. DOI:10.1016/j.matchemphys.2014.03.046.

7. Hackbarth, F.V., Maass, D., Souza, A. A.U., Vilar, V.J.P. Selene, M.A. \& Souza, G.U. (2016). Removal of hexavalent chromium from electroplating wastewaters using marine macroalga Pelvetia canaliculata as natural electron donor. Chem. Eng. J. 290, 477-489. DOI: 10.1016/j.cej.2016.01.070.

8. Memon, J.R., Memon, S.Q., Bhanger, M.I., El-Turki A., Hallam, K.R. \& Allen, G.C.(2009). Banana peel: A green and economical sorbent for the selective removal of $\mathrm{Cr}(\mathrm{VI})$ from industrial wastewater, Colloids Surf., B: Biointerfaces. 70 (2), 232-237. DOI:10.1016/j.colsurfb.2008.12.032.

9. Sfaksi, Z., Azzouz, N. \& Abdelwahab, A. (2014). Removal of $\mathrm{Cr}(\mathrm{VI})$ from water by cork waste, Arab. J. Chem. 7 (1), 37-42. DOI:10.1016/j.arabjc.2013.05.031.

10. Volesky, B., \& Holan, Z.R. (1995). Biosorption of heavy metals. Biotechnol. Progr. 11(3), 235-250. DOI: 10.1021/ bp00033a001.

11. Kushwaha, S., Sreedhar, B. \& Sudhakar, P.P. (2012). A spectroscopic study for understanding the speciation of $\mathrm{Cr}$ on palm shell based adsorbents and their application for the remediation of chrome plating effluents, Bioresour. Technol. 116, 15-23. DOI: 10.1016/j.biortech.2012.04.009.

12. Souza, F.B., Brandão, H.L., HackBarth, F.V., Souza, A.A.U., Boaventura, R.A.R., Selene, M.A., Souza, G.U. \& Vilar, V.J.P. (2016). Marine macro-alga Sargassum cymosum as electron donor for hexavalent chromium reduction to trivalent state in aqueous solutions. Chem. Eng. J. 283, 903-910. DOI: 10.1016/j.cej.2015.08.038.

13. Kuppusamy, S., Thavamani, P., Megharaj, M., Venkateswarlu, K. Lee, Y.B. \& Naidu R. (2016). Oak (Quercus robur) Acorn Peel as a Low-Cost Adsorbent for Hexavalent Chromium Removal from Aquatic Ecosystems and Industrial Effluents. Water, Air, Soil Pollut. 227, 62. DOI: 10.1007/s11270016-2760-z.

14. Netzahuatl-Muñoz, A. R., Morales-Barrera, L., CristianiUrbina, M.d.C. \& Cristiani-Urbina, E. (2012). Hexavalent chromium reduction and chromium biosorption by Prunus serotina bark. Fresenius Environ. Bull. 21, 1793-1801.

15. Chakravarty, R., Khan, M.M.R., Das, A.R. \& Guha, A.K. (2013). Biosorptive removal of chromium by husk of Lathyrus sativus: evaluation of the binding mechanism, kinetic and equilibrium study. Eng. Life Sci. 13, 312-22. DOI: 10.1002/ elsc. 201200044. 
16. López-García, M., Lodeiro, P., Herrero, R., Barriada, J.L., Rey-Castro, C., David, C. \& Sastre de Vicente, M.E. (2013). Experimental evidences for a new model in the description of the adsorption-coupled reduction of $\mathrm{Cr}(\mathrm{VI})$ by protonated banana skin, Bioresour. Technol. 139, 181-189. DOI: 10.1016/j. biortech.2013.04.044.

17. Gupta, V.K., Pathania, D., Agarwal, S., Sharma, S. (2013). Removal of Cr(VI) onto Ficus carica biosorbent from water. Environ. Sci. Pollut. Res. 20, 2632-2644. DOI: 10.1007/ s11356-012-1176-6.

18. Doke, K.M., Yusufi, M. Joseph, R.D. \& Khan, E.M. (2012). Biosorption of hexavalent chromium onto wood apple shell: equilibrium, kinetic and thermodynamic studies. Desalin. Water Treat. 50, 170-179. DOI: 10.1080/19443994.2012.708565.

19. Ponou, J., Kim, J., Wang, L.P., Dodbiba, G. \& Fujita, T. (2011). Sorption of $\mathrm{Cr}(\mathrm{VI})$ anions in aqueous solution using carbonized or dried pineapple leaves. Chem. Eng. J. 172, 906-913. DOI: 10.1016/j.cej.2011.06.081.

20. Park, D., Yun, Y. S. \& Park, J. M. (2005). Studies on hexavalent chromium biosorption by chemically treated biomass of Ecklonics sp. Chemosphere. 60, 1356-1364. DOI: 10.1016/j. chemosphere.2005.02.020.

21. Ahmed, M., Khirstova, P. \& Icho, G., (2005). Comparative study of tannins of Acacia spp an indigenous tanning material in Sudan with Acacia mearnsii. Suranaree J. Sci. Technol. 12(4), 259-265.

22. Ramakul, P., Yanachawakul, Y., Leepipatpiboon, N. \&Sunsandee, N., (2012). Biosorption of palladium(II) and platinum (IV) from aqueous solution using tannin from Indian almond (Terminalia catappa L.) leaf biomass: Kinetic and equilibrium studies. Chem. Eng. J. 193, 102-111. DOI: 10.1016/j.cej.2012.04.035.

23. Clesceri, L.S., Greenberg, A.E. \& Eaton, A.D. (1998). Standard Methods for the Examination of Water and Wastewater (20th ed.). Washington, DC., USA: American Public Health Association, American Water Work Association and Water Environment Federation.

24. Albadarin, A.B., Glocheux, Y., Ahmad, M.N.M., Walker, G.M. \& Mangwand, C. (2014). Novel comparison of kinetic models for the adsorption-coupled reduction of $\mathrm{Cr}(\mathrm{VI})$ using untreated date pit biomaterial. Ecol. Eng. 70, 200-205. DOI: 10.1016/j.ecoleng.2014.05.002.

25. Kotas, J. \& Stasicka, Z. (2000). Chromium occurrence in the environment and methods of its speciation, Environ. Pollut. 107, 263-283. DOI: 10.1016/S0269-7491(99) 00168-2.

26. Park, D., Lim, S.R., Yun, Y.S., Yun, Y.S. \& Park, J.M. (2007). Reliable evidences that the removal mechanism of hexavalent chromium by natural biomaterials is adsorptioncoupled reduction. Chemosphere, 70 (2), 298-305. DOI: 10.1016/j.chemosphere.2007.06.007.

27. Park, D., Lim, S.R., Yun, Y.S. \& Park, J.M. (2008). Development of a new $\mathrm{Cr}(\mathrm{VI})$-biosorbent from agricultural biowaste. Bioresour. Technol. 99, 8810-8818. DOI: 10.1016/j. biortech.2008.04.042.

28. Park, D, Lee, D.S. \& Park, J.M. (2011). Consideration of the methods for evaluating the $\mathrm{Cr}(\mathrm{VI})$-removing capacity of biomaterial. Korean J. Chem. Eng. 28(3), 831-836. DOI: 10.1007/s11814-010-0453-7.

29. Dittert, I.M., Brandão, H.L., Pina, F., Silva, E.A.B., Souza, S.M.A.G., Souza, A.A., Botelho, C.M.S., Boaventura, R.A.R. \& Vilar, V.J.P. (2014). Integrated reduction/oxidation reactions and sorption processes for $\mathrm{Cr}(\mathrm{VI})$ removal from aqueous solutions using Laminaria digitata macro-algae. Chem. Eng. J. 237, 443-454. DOI: 10.1016/j.cej.2013.10.051. 